Supplement of Saf. Nucl. Waste Disposal, 1, 265-266, 2021

https://doi.org/10.5194/sand-1-265-2021-supplement

(c) Author(s) 2021. CC BY 4.0 License.

Supplement of

\title{
What happens when the nuclear power plant goes? Social and economic consequences of dismantling for the site and its population
}

\author{
Caroline Kramer \\ Correspondence to: Caroline Kramer (caroline.kramer@kit.edu)
}

The copyright of individual parts of the supplement might differ from the article licence. 


\section{Research Questions}

What happens in the communities after the phase-out?

- What are the social and economic consequences for local people?

- Which actors do they trust?

- What effects do people fear for themselves and their local communities?

- How do experts from politics and business evaluate this process?

- What can be learned from this for future dismantling processes?

Methods

- Four investigated communities with nuclear power plants in various stages of decommissioning (Obrigheim (closed 2005), Biblis (closed 2011), Neckarwestheim and Philippsburg (partially closed at the time of the survey in 2014).

- 38 qualitative interviews with 38 people from politics, business, interest groups.

- Standardized surveys in 2014 , response 1.586 (response rate $22 \%$ ).

- "Future workshop" with representatives of the communities and the population: different scenarios for the further development of the community.

- During the project: ongoing public discussion about interim storage facilities and repositories at the sites of this communities.
Findings: little trust in stakeholders, concern about jobs and tax revenues

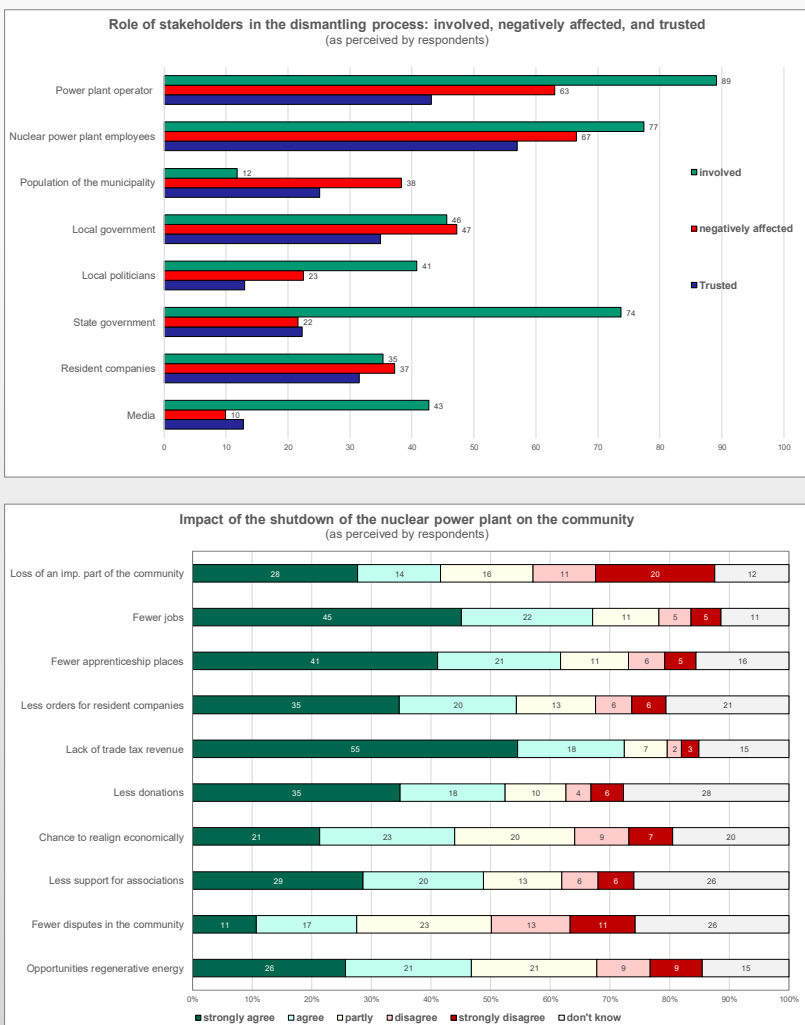

Electricity will become more expensive because the NPP will be

dismantled. Thank you very much you Greens!

\section{Away
with it!}

Nobody but nobody will take away the nuclear waste from Philippsburg in the next generations! Who has interest in it except the few Philippsburgers?

Good that

it is off. :)

$\begin{gathered}\text { Clean and safe energy, } \\ \text { only because of Tsunami } \\ \text { in Japan the German } \\ \text { demonizes the nuclear } \\ \text { energy. }\end{gathered}$
waste.

- First-hand knowledge in demand: great trust in power plant employees, but also in operators, less in political actors.

- Negative consequences expected for these groups in particular, but also for local government and local business.

- Negative consequences of the shutdown: especially in the decrease of tax revenues and the decrease jobs and apprenticeships. companies as supporters of associations and non-profit organizations.

- But also: opportunities for new regenerative energies, such as the biomass cogeneration plant in Obrigheim.

- Many are relieved that the power plant is being shut down.

- Major concerns:

radioactive waste will be a big problem for the next generation $\mathbf{( 7 5 \% )}$

the own community could after the temporary interim storage $(63 \%)$
- Withdrawal of energy even become a repository

\section{Future Workshop}

What can the future of our community look like?

After analyzing the strengths of each community, these key topics were developed together:

1) Strong Community

2) Energy storage and transport

3) Future tourism region

4) Power plant site as a recreational park

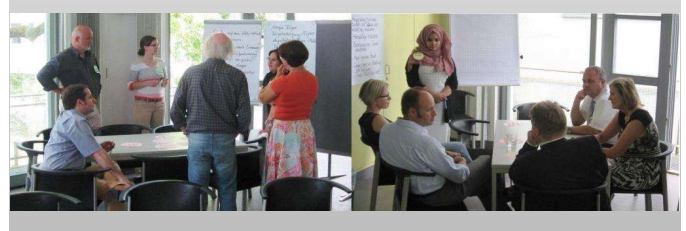

\section{Conclusion}

- Communities are seriously affected by the shutdown, different starting points of the site determine the future.

- Different individual assessment of the risks of the NPP, are depending on values and sources of information.

- Committment depends on identification with the community, common concern about permanent damage to the image.

- Majority would like to stay at the site, younger people tend to move away.

- Early information, transparency of political and strategic decisions, and opportunities for participation are essential for a successful process.

Prof. Dr. Caroline Kramer, KIT, IfGG Kontakt: caroline.kramer@kit.edu, https://www.ifgg.kit.edu/index.php More: https://journals. openedition. org/allemagne/2033 Project FoRK, financed by BMBF, FKZ $15 S 9062$ 